\title{
Futbol Taraftarlarının Seyircilik Durumları ile Spor Takımı Evangelizm (eFANgelizm) İlişkisi Üzerine Ampirik Bir Araştırma
}

\author{
Ali ERDOĞAN ${ }^{1}$, Mehmet ÖZTAŞ ${ }^{2}$ ve Erkan Faruk ȘIRİN ${ }^{3}$
}

\section{$\ddot{\mathrm{O} z}$}

Bu çalı̧smada spor takım eFANgelizmi ilefutbol izleyicilerinin seyirci, taraftar ve fanatik tutumları arasındaki ilişkiyi ortaya koymak amaçlanmıştır. Bu amaç Beşiktaş, Fenerbahçe, Galatasaray ve Trabzonspor taraftarları olmak üzere dört ayrı ana kütleden toplanan toplam 362 futbol izleyicisi üzerinde test edilmiştir. Verilerin toplanmasında futbol izleyicilerinin düzeylerini (seyirci, taraftar, fanatik) belirleyebilmek amacıyla "Futbol Taraftarı Fanatiklik Ölçeği" ve futbol izleyicilerinin takımla ilgili inançların ve takım merkezli etkileşimlerin hararetli bir şekilde yayılması yoluyla harekete geçirilen taraftar davranışııı belirlemek için ise "Spor Takımı Evangelizmi (eFANgelizmi) Ölçeğı" kullanılmıştır. Verilerin analizinde normallik sınaması yapılarak verilerin normal dağıldığı tespit edilmiş ve parametrik testlerden yararlanılmıştır. Araştırmaya katılan futbol izleyicilerinin taraftar fanatiklik ölçeğine göre \%34,8’i (126) fanatik, \% 35,4 ü (128) taraftar ve \%29,8’i seyircidir (sporsever); futbol izleyicilerinden fanatiklerin spor takım1 eFANgelizmi seyirci ve taraftara göre anlamlı derecede yüksek bulunmuştur. Ayrıca spor takımı eFANgelizmi ile futbol taraftarı fanatiklik (şiddete yönelik düşünce/eylem eğilimi ve kurumsal aidiyet) alt boyutları arasında pozitif yönlü bir ilişki tespit edilmiştir. Buradan hareketle, fanatik ve taraftar olan eFANgelistlerin herhangi bir beklenti içerisine girmeden taraftarı oldukları takımları tanıtarak, takım merkezli etkileşimlerin yayılmasını sağladıkları söylenebilir.

Anabtar Kelimeler: Marka evangelizmi, eFANgelizmi, Fanatiklik, Taraftar

\section{An Empirical Research on the Correlation between Spectatorship Status of Football Fans} and Sport Team Evangelism (eFANgelism)

\begin{abstract}
The aim of this research is to reveal the correlation between sports team eFANgelism and the spectator, fan and fanatic attitudes of football Spectators. Besiktas, Galatasaray Fenerbahce, Trabzonspor fans, this goal was tested on a total of 362 football spectators gathered from four separate main masses: Galatasaray and Trabzonspor. The "football fan fanaticism scale "was used to determine the level of Football Spectators (spectators, fans, fanatics) and the" sports team evangelism scale "was used to determine fan behavior mobilized by the heated dissemination of Football Spectators' beliefs about the team and team-centered interactions. In the analysis of the data, a normality test was performed and it was determined that the data was distributed normally and parametric tests were used. According to the fan fanaticism scale, 34.8\% (126) were fanaticism, 35.4\% (128) were fans and 29.8\% were spectators (sports fans); sports team eFANgelism of football spectators was found to be significantly higher than spectators and fans. In addition, a positive correlation was found between sports team eFANngelism and the lower dimensions of football fan fanaticism (tendency to think/act towards violence and institutional belonging). Based on this, it can be said that eFANgelists, who are fanatics and fans, promote the teams they are supporters of without any expectations, ensuring the spread of team-centered interactions.
\end{abstract}

Key Words: Brand evangelism, eFANgelism, Fanaticism, Fan

Atıf İçin / Please Cite As:

Erdoğan, A., Öztaş, M. ve Şirin, E. F. (2021). Futbol taraftarlarının seyircilik durumları ile spor takımı evangelizm (eFANgelizm) ilişkisi üzerine ampirik bir araştırma. Manas Sosyal Araştırmalar Dergisi, 10(1), 476-484.

Geliş Tarihi / Received Date: 28.01.2020

Kabul Tarihi / Accepted Date: 02.10.2020

\footnotetext{
1 Öğr. Gör. - Karamanoğlu Mehmetbey Üniversitesi Beden Eğitimi ve Spor Yüksekokulu, aerdogan@kmu.edu.tr ORCID: 0000-0001-8306-5683

2 Öğr. Gör. - Erzincan Binali Yıldırım Üniversitesi Beden Eğitimi ve Spor Yüksekokulu,oztasm24@gmail.com

iD ORCID: 0000-0003-4689-6490

3 Prof. Dr. - Selçuk Üniversitesi Spor Bilimleri Fakültesi, erkanfaruk@yahoo.com

iD ORCID: 0000-0002-6837-7758
} 


\section{Giriş}

Günümüzde futbol kulüpleri, fiyat dışı bir rekabet aracı olarak markaları ile taraftarları arasında güçlü duygusal bağlar oluşturmaya yönelik işbirliği kapsamında ilişkiler kurmaya başlamışlardır. Spor kulüpleri iliş̧ki pazarlaması ile taraftarlarını nasıl müşteri olarak çekecek, geliştirecek ve elde tutabilecekleriyle ilgileniyorlar (Scott vd., 2017). Bu amaçla, ilişki yönetimi ile marka odaklı topluluklar oluşturmaya, taraftarların deneyimlerini gönüllü bir şekilde paylaşmalarını sağlayarak taraftarlarının marka evangeliztine dönüşmeleri için çabalamaktadırlar. Marka evangelizti, aktif olarak başkalarının satın alma davranışını pozitif yönde etkilemek için bir markanın tanıtımını yapan ve markayla ilgili iyi haberlerin yayılmasına katkı sağlayan ve bu katkıyı herhangi bir beklenti içerisine girmeden gerçekleştiren tüketiciler olarak ele alınmaktadır (Matzler vd., 2007). Marka evangelizmi, ağızdan ağıza pazarlamanın bir uzantısıdır ve "lobicilik" ile ilgili davranış kalıplarını içerir (Hsu 2018). Pimentel ve Reynolds’e (2004) göre evangelizm kelimesi aslında tüketici tutkusunun misyoner bileşenine vurgu yapan davranışsal bir çıktısıdır.

Spor pazarlamacıları için önemli bir değişken olmaya aday olan marka evangelizmi, spor taraftarının evangelizt davranışını belirlemek amacıyla Sosyal Kimlik Teorisinden faydalanarak Dwyer, Greenhalgh ve LeCrom (2015) tarafindan "evangelizm" sözcügünün içerisine "fanatik" kelimesinin kısaltması olan "fan" sözcügünü yerleştirerek "eFANgelizm” olarak kullanmıştır. Araştırmacılar tarafindan eFANgelizm kavramı marka elçiliğinin ve spor takımı sadakatinin bir uzantısı olarak sunulmuştur. eFANgelizm, "spor taraftarlarının takımın markasına tutkuyla bağlanmasıyla ortaya çıkan, takımla ilgili inançları harekete geçirilen ve hararetle yayılmasıyla sonuçlanan ve takım merkezli etkileşimleri başlattıkları bir davranışsal bağllık biçimi” olarak kavramlaştırılmıştır (Dwyer vd., 2015). Spor kulübü ile taraftar arasında oluşturulan bu duygusal deneyimin içselleştirilmesi taraftarların kimlik, topluluk ve aidiyet duygularına hitap edecek şekilde benlik imajına dönüştürülebilir. Bu şekilde bir tanımlama, markanın gelecekteki sadakatinin korunmasını sağlayabilecektir, evangeliztler arasındaki bağlılı̆̆ı takıma duyulan sevgi ya da tutkuyu da geçerek "aklın ötesinde bir sadakat" boyutunu da aştı̆̆ını belirtmektedir (Roberts, 2004).

Spor pazarlama yazınında, marka evangelizmine yönelik çok az sayıda çalışma yer almakla beraber bu çalısmaların son dönemlerde yoğunlaştı̆̆ görülmektedir. Literatürde ilk olarak eFANgelizm kelimesini literatüre sokan ve spor takımı eFANgelizmi ölçeğini geliştiren Dwyer vd. (2015) marka evangelizmini taraftarlar açısından ele almışlardır. Yine Dwyer, Greenhalgh ve LeCrom (2016) spor takımı eFANgelizmi konu aldıkları diğer bir çalışmalarında ana spor taraftarları arasındaki psikometrik ve davranışsal bölümleme aracı olarak eğilim ve davranışsal farklılıkları araştırmıştır. Ülkemizde ise bu ölçeğin (Spor Takımı eFANgelizm Ölçeği) Türkçeye uyarlama çalışması Yüksekbilgili (2017) tarafından yapılmıştır. Bununla beraber Yüksekbilgili (2018) Facebook ve Twitter üzerinde yaptığı diğer bir çalışmasında birkaç demografik faktörün (cinsiyet, kuşak (X,Y), medeni durum, sahip olunan çocuk sayısı ve eğitim seviyesi) eFANgelizm ile ilişkisi incelenmiştir. Konu ile ilgili bir başka çalışmada Büyükakgül, Yüce ve Katırc1 (2018) futbol takımlarının amaca yönelik pazarlama uygulamalarının eFANgelizm davranışı üzerine etkisini incelemiştir. Büyükakgül ve Engin (2018) taraftarların sosyal kimliklerinin efangelizm davranışlarına etkisini ve efangelizm davranışının taraftarların takımlarının lisanslı ürünlerini satın alma niyetine üzerine etkisini incelemiştir. Küçükibiş ve Yurtsızoğlu (2019) ise yüksek lisans öğrencilerinin spor takımlarının evangelizm tutumlarını belirlemek ve evangelizt davranışları incelemiştir. Hsu (2018) ise markaların evangelizmle ilgili davranışsal kararlarının sanal ortamda (sosyal paylaşım sitelerinde) taraftarlar üzerindeki etkilerini araştırmıştır. Bu araştırmalar dikkate alındığında spor izleyicilerinin taraftarlık özelliklerinin [psikometrik ve davranışsal benzerliklerinin (seyirci, taraftar, fanatik)] eFANgelizm davranışı üzerine etkisinin konu edildiği herhangi bir araştırmaya rastlanmamıştır.

Spor pazarlamacıları spor izleyicilerini tanımlamak için genellikle müşteri guruplarının takımlarıyla olan ilişki ve davranışlarını incelemişlerdir. Spor izleyicileri kendilerini bir spor takımıyla ilişkilendirdikten sonra taraftar deneyiminin çeşitli bileşenlerine aktif olarak katılarak takımla olan ilişkilerini geliştirir (Wann, Grieve, Zapalac ve Pease, 2008). Bu bileşenler maçları canlı olarak izlemek, televizyonda izlemek, ürün satın almak ve taraftarı olduğu takımın ürünlerini giymek vb. olabilir. Herkesin farklı ilgi ve bağlılık dereceleri vardır, bu yüzden farklı izleyici grupları vardır.

Futbolda taraftar, fanatik, seyirci (sporsever) gibi kavramların kullanıldığ görülmektedir (Taşmektepligil, Çankaya ve Tunç, 2015). Ancak bu kavramlarının birbirinden farklı olduğu ve bunlar arasında bir ayırım yapılması gerekmektedir (Sivrikaya, 2015). Jones (1997) taraftarları tutmuş olduğu takımı daha yoğun şekilde takip eden ve her gününün bir parçasını tutmuş olduğu takıma ayırıp kendilerini 
ona adarlar iken, seyircilerin genellikle bir spor müsabakasını izlediklerini ve bunu unuttuklarını öne sürmektedir (Mountinho, Dionisio ve Leal, 2007). Yapılan başka bir tanımlamaya göre ise seyirci, bir spor müsabakasını gerçekleștiği anda izleyen ya da dinleyen kimseler; taraftar ise lig, takım ya da sporcu gibi bir spor öğesine yüksek düzeyde bağlı olan bireylerdir (Çokpartal, 2015). Fanatik ise, tuttuğu takıma aşırı derecede tutkuyla bağlanmış olan kişiye denilmektedir (Taşmektepligil vd., 2015).

Spordaki sadakat kavramının taraftarlık ile ilişkisinin incelenmesine yönelik literatürde pek fazla bilgi veya bulgu yer almamaktadır. Bunun yanında taraftarlık davranışları ve evangelizm (eFANgelizm) arasındaki ilişskiyi konu alan ulusal ya da uluslararası herhangi bir araştırmaya rastlanmamıştır. Bu nedenle, sosyal kimlik teorisinin rehberliğinde yapılan bu çalışmada, spor takım evangelizmi, futbol izleyicilerinin benzer psikometrik ve davranışsal ölçümlere dayanarak seyirci, taraftar ve fanatik tutumları arasındaki ilişkiyi ortaya koymak amaçlanmıştır. Böylece, bu araştırma sonuçlarının spor tüketici davranışına ilişkin veri tabanını genişletmek için faydalı olacağı düşünülmektedir.

\section{Yöntem}

Araştırmada yöntem olarak ilişkisel tarama yöntemi kullanılmıştır. Bu çalışmada amaçlara uygun olarak Betimsel analiz ve Bağıntısal Araştırma Modeli kullanılmıştır. Bağıntısal araştırma modeli mevcut problemi, bu problemle karşılaşılan durumları, değişkenler ile değiş̧kenler arası ilişkileri belirtmektedir (Kurtuluş, 1998, s. 310). Betimsel model, geçmişte ya da halen var olan bir durumu var olduğu şekliyle betimlemeyi amaçlayan araştırma yaklaşımlarıdır. Araştırmaya konu olan kişi ya da nesne kendi koşulları içinde ve olduğu gibi tanımlanmaya çalışılır. Araştırılan nesne herhangi bir şekilde, etkilenmeye, değiştirilmeye, dönüştürülmeye çalışılmaz. Bilinmek istenen şey her ne ise o alınmaya çalışlır (Karasar, 2014, s. 77). Araştırmada bilgiler ise anket tekniğinden faydalanılarak elde edilmiştir. Katıllımcılar ise seçkisiz/tesadüfî örnekleme yöntemiyle belirlenmiştir.

\section{Evren - Örneklem}

Araştırmanın evrenini, Türkiye'deki profesyonel futbol kulüplerinin izleyicileri oluştururken; örneklemini ise Türkiye Futbol Süper Ligi 2018-2019 sezonunda yer alan çalışmaya gönüllü olarak katılmayı kabul eden Konya ilinde Beşiktaş, Fenerbahçe, Galatasaray ve Trabzonspor futbol kulüplerinin takımlarının üniversiteli futbol izleyicileri oluşturmaktadır. Söz konusu izleyicilerin sayısının bilinmemesi ya da herhangi mevcut bir taraftar listesinin olmaması, zaman ve maliyet kısıtları nedeniyle araştırmanın çalışma grubu üniversite öğrencilerini (lisans ve Yüksek lisans) kapsayacak şekilde sınırlandırılmıştır. Konya ilinde yaşayan futbol izleyicilere arasında yapılan bir değerlendirmeye göre Galatasaray taraftarı olanların oranı $\% 37$, Fenerbahçe'yi tutanların oranı $\% 33$, Beşiktaş taraftarı olanlar $\% 20$, Trabzonsporlular ise $\% 5$ olarak hesaplanmışır (https:/ /www.fotomac.com.tr Erişim tarihi: 08.08.2019).

\section{Veri Toplama Araçları}

Araştırmada veri toplamak amacıyla, "Futbol Taraftarı Fanatiklik Ölçeği”, "Spor Takımı Evangelizmi (Fangelizm) Ölçeği” ve "Kişisel Bilgi Formu" kullanılmışırı.

Futbol Taraftarı Fanatiklik Ölçeği (FTFÖ). Araştırmanın amacına uygun olarak çalışmaya katılan futbol izleyicilerinin seyircilik durumlarının (seyirci, taraftar ve fanatik) belirlenmesi amaciyla Taşmektepligil vd. (2015) tarafından geliştirilen "Futbol Taraftarı Fanatiklik Ölçeği” kullanılmışıtır. Ölçek 4'lü likert tipinde hazırlanmış ve tamamı olumlu 13 maddelerden oluşmuştur. Ölç̧eğe verilen cevaplar Kesinlikle Katıllyorum (1), Katıllyorum (2), Katılmıyorum (3) ve Hiç, Katılmıorum (4) biçiminde belirlenmiştir. Futbol izleyicilerinin seyircilik durumlarını belirlemek için seyircilerin 13 soru üzerinden almış olduğu toplam puan belirlenen ranj aralığı ile değerlendirilmiş ve toplam puan 13-21 arasında ise "futbolsever", 22-30 arasında ise "takım taraftarı", 31-52 arasında ise "fanatik" olarak sınıflandırılmıştır. FTFÖ'den alınan minimum puanı 13, maksimum puanı 52 olarak hesaplanmıştır. Bunun yanında FTFÖ iki alt boyutlu olarak ta değerlendirilebilmektedir. FTFÖ'nin ilk 8 maddelik kısmı (birinci faktör) taraftarların "şiddete yönelik düşünce ve eylem eğilimleri”; son 5 maddelik kısmı ise (ikinci faktör), "kurumsal aidiyet" duygusuyla ilgili tutumları ölçmektedir. Ölçeğin yapı geçerliğine yönelik yapılan AFA ve DFA sonuçları, ölçek maddelerinin kabul edilebilir düzeyde faktör yüküne sahip olduğunu göstermiş ve ölçeğin iki faktörlü bir yapıda olduğunu ortaya koymuştur. Ölçeğin genel iç iç tutarllık katsayısı 0.875 bulunmuştur (Taşmektepligil vd., 2015).

Spor Takımı Evangelizmi (Fangelizm) Ölçeği(STEÖ). Spor izleyicilerinin efangelizm davranışlarını ölçmek üzere Dwyer, Greenhalgh ve LeCrom (2015) tarafindan geliştirilen, Yüksekbilgili 
(2017) tarafından Türkçeye uyarlanan “Spor Takımı Evangelizmi (eFANgelizm) Ölçeğı” kullanılmıştır. Orijinalinde STEÖ 14 sorudan ve alt boyuttan (savunma, reklam, kışkırtma ve özümseme) oluşmaktadır. Yüksekbilgili (2017) tarafindan yapılan uyarlama çalışması sonucunda tek faktörlü yapıya sahip olarak belirlenmiş ve orijinal ölçek 12 soruluk forma dönüştürülmüştür. Soruların yantlanması için 5'Li likert ölçeği kullanılmıştır. Yapılan AFA sonucunda ölçek maddelerinin kabul edilebilir düzeyde faktör yüküne sahip olduğu belirlenmiş ve ölçeğin genel iç iç tutarlllık katsayıs1 0.936 olarak bulunmuştur (Yüksekbilgili, 2017).

\section{Verilerin Analizi}

Elde edilen veriler, SPSS programı vasıtasıyla bilgisayar ortamına aktarılmıştır. Anket sorularına verilen değerler yeniden kodlanmıştır. Bazı demografik değişkenler yeniden tanımlanarak veri dönüştürme işlemi uygulanmıştır. Verilerin analizinde normallik sınaması yapılarak verilerin normal dağıldığı tespit edilmiş ve parametrik testlerden yararlanılmıştır. Bunun yanında ikiden fazla grubun karşılaştırılmasında ise tek yönlü varyans analizi (ANOVA) kullanılmıştır. Farkların hangi gruplar arasında olduğunu belirlemek için Tukey HSD testi, seyircilik tutumları ve eFANgelizm düzeyi arasındaki ilişki Pearson korelasyon analizi, siddete yönelike düsünceve eylem eğilimikurumsal aidiyet tutumlarının spor takımı eFANgelizm düzeyi üzerindeki etkisi ise regresyon analizi kullanılarak tespit edilmiştir.

\section{Bulgular}

Tablo 1. Taraftarlarm Demografik Özellikleri

\begin{tabular}{|c|c|c|c|c|c|c|}
\hline \multicolumn{2}{|c|}{ Değişkenler } & \multirow{3}{*}{$\begin{array}{c}\begin{array}{c}\text { Galatasaray } \\
(\boldsymbol{n}=151)\end{array} \\
52(\% 34.4) \\
99(\% 65.6)\end{array}$} & \multirow{3}{*}{$\begin{array}{c}\begin{array}{c}\text { Fenerbahçe } \\
(\boldsymbol{n}=95)\end{array} \\
35(\% 36.8) \\
60(\% 63.2)\end{array}$} & \multirow{3}{*}{$\begin{array}{c}\begin{array}{c}\text { Beşiktas } \\
(\boldsymbol{n}=84)\end{array} \\
22(\% 26.2) \\
62(\% 73.8)\end{array}$} & \multirow{3}{*}{$\begin{array}{c}\text { Trabzonspor } \\
(\boldsymbol{n}=32)\end{array}$} & \multirow{3}{*}{$\begin{array}{c}\begin{array}{c}\text { Toplam } \\
(\boldsymbol{n}=362)\end{array} \\
118(\% 32.6) \\
244(\% 67.4)\end{array}$} \\
\hline & $17-20$ yaş & & & & & \\
\hline Yaş & $<20$ yaş & & & & & \\
\hline \multirow{2}{*}{ Cinsiyet } & Kadın & $50(\% 33.1)$ & $28(\% 29.5)$ & $24(\% 28.6)$ & $5(\% 15.6)$ & $107(\% 29.6)$ \\
\hline & Erkek & $101(\% 66.9)$ & $67(\% 70.5)$ & $60(\% 71.4)$ & $27(\% 84.4)$ & $255(\% 70.4)$ \\
\hline \multirow{2}{*}{ Ĕgitim } & Lisans & $141(\% 93.4)$ & $86(\% 90.5)$ & $80(\% 95.2)$ & $80(\% 93.7)$ & $337(\% 93.1)$ \\
\hline & Yüksek lisans & $10(\% 6.6)$ & $9(\% 9.5)$ & $4(\% 4.8)$ & $2(\% 6.3)$ & $25(\% 6.9)$ \\
\hline
\end{tabular}

Tablo 1'e göre Galatasaray taraftarlarının \%34,4'ü 17-20 yaş aralı̆̆ındayken \%65,6's1 20 yaş ve üstünde olduğu görülmektedir. Galatasaray taraftarlarının \%6,6's1 yüksek lisans ve \%93,4'ü üniversite mezunu iken genel olarak taraftarların yaklaşık \%33’ü kadınlardan \%67'si da erkeklerden oluşmaktadır. Fenerbahçe taraftarlarının \%36,8’i 17-20 yaş aralığındayken \%63,2's1 20 yaş ve üstünde olduğu görülmektedir. Fenerbahçe taraftarlarının \%9,5'i yüksek lisans ve \%90,5’i üniversite mezunu iken genel olarak taraftarların yaklaşık \%30'u kadınlardan \%70'i da erkeklerden oluşmaktadır. Beşiktaş taraftarlarının $\% 26,2$ 'si 17-20 yaş aralı̆̆ındayken \%73,8’i 20 yaş ve üstünde olduğu görülmektedir. Beşiktaş taraftarlarının $\%$ 4,8'i yüksek lisans ve \%95,2'si üniversite mezunu iken genel olarak taraftarların yaklaşı \%16's1 kadınlardan \%84'ü da erkeklerden oluşmaktadır. Trabzonspor taraftarlarının ise \%32,6's1 17-20 yaş aralığındayken \%67,4’ü 20 yaş ve üstünde olduğu görülmektedir. Trabzonspor taraftarlarının \%6,3’ü yüksek lisans ve \%93,7'si üniversite mezunu iken genel olarak taraftarların yaklaşı \%6'sı kadınlardan $\% 94$ 'ü de erkeklerden oluşmaktadır.

Tablo 2. Taraftarlarm Seyircilik Tutumlar ve eF ANgelizm Düzeyi Genel Profili

\begin{tabular}{|c|c|c|c|c|c|}
\hline Ölçekler & $\mathbf{N}$ & $\mathbf{X}$ & ss & Min & Max \\
\hline \multicolumn{6}{|l|}{ Taraftarın Seyircilik Tutum Alt Boyutları } \\
\hline Şiddete Yönelik Düşünce ve Eylem Eğilimi & 362 & 2.21 & 0.77 & 1 & 4 \\
\hline Kurumsal aidiyet & 362 & 1.90 & 0.77 & 1 & 4 \\
\hline \multicolumn{6}{|l|}{ eFANgelizm Düzeyi } \\
\hline eFANgelizm & 362 & 3.18 & 1.08 & 1 & 5 \\
\hline
\end{tabular}

Tablo 2 incelendiğinde, taraftarların vermiș oldukları cevaplara göre örneklemin taraftarların seyircilik tutum alt boyutundan şiddete yönelike dïş̈̈nce ve eylem eğilimi tutum düzeyinin, ortalamanın üstünde $(\mathrm{X}=2.21 \pm$ .77), kurumsal aidiyet tutum düzeyinin ortalamanın altında ( $\mathrm{M}=1.90 \pm .77)$ olduğu görülmektedir. Hem kurumsal aidiyet hem de şiddete yönelik düşünce ve eylem eğilimi açısından görüşleri alınan taraftarların profilleri incelendiğinde; kurumsal aidiyet tutumlarının düşük, şiddete yönelik düşünce ve eylem eğilimi tutumlarının ise orta düzey olduğu görülmüştür. Taraftarların eFANgelizm düzeyi incelendiğinde ise, genel eFANgelizm düzeyinin ortalamanın üzerinde olduğu $(\mathrm{M}=3,18 \pm 1.08)$ görülmektedir. 
Tablo 3. Taraftarlarn Seyircilik. Durumlarn İle İlgili Dağıllmlar

\begin{tabular}{lcc}
\hline Taraftarların Seyircilik Durumu & $\mathbf{n}$ & $\mathbf{\%}$ \\
\hline Sporsever & 108 & 29.8 \\
Takım Taraftarı & 128 & 35.4 \\
Fanatik & 126 & 34.8 \\
\hline
\end{tabular}

Tablo 3 incelendiğinde, taraftarların seyircilik durumlarına göre \% 34,8’ fanatik, \% 35,4’ü takım taraftar1 ve \% 29,8'i ise sporsever olarak tespit edilmiştir.

Tablo 4. Taraftarlarn Seyircilik Durumlarna Göre eFANgelizm

\begin{tabular}{ccccccccc}
\hline & & Taraftarların Seyircilik Durumu & N & X & Ss & F & p & Anlamlılık \\
\hline \multirow{3}{*}{ eFANgelizm } & A & Sporsever & 108 & 2.20 & .89 & 101.082 & .000 & C $>$ A,B \\
& B & Takım Taraftar1 & 128 & 3.43 & .89 & & & B $>$ A \\
& C & Fanatik & 126 & 3.78 & .82 & & & \\
\hline
\end{tabular}

Tablo 4'te taraftarların eFANgelizm düzeylerinin seyircilik durumlarına göre anlamlı bir farklılık gösterip göstermediğini tespit etmek amacıyla yapılan tek yönlü varyans analizi (ANOVA) sonuçlanı incelendiğinde, eFANgelizm puanı en yüksek seyircilerin fanatik taraftarlar ( $X=3.78)$ olduğu göze çarpmaktadır. Bu düzeyi daha sonra takım taraftarları $(\mathrm{X}=3.43)$ takip etmektedir. $\mathrm{Bu}$ taraftarların ortalamalarının ortanın oldukça üzerinde bir eFANgelizm puanına sahip olduğunu söylemek mümkündür. Daha sonra ise sporseverlerin $(\mathrm{X}=2.20)$ eFANgelizm düzeyleri gelmektedir. İstatistiksel açıdan bakıldığında ise seyircilik durumu ile eFANgelizm düzeyi arasında anlamlı farklılık söz konusudur $(p<, 05)$. Gruplar arasındaki farklılığın anlamlı olduğunu tespit etmek amacıyla yapılan Tukey HSD verileri ise farklılığın, sporseverler ile fanatik ve takım taraftarları arasında olduğunu göstermiştir. Yani fanatik ve takım taraftarı olan seyircilerin eFANgelizm düzeyleri sporseverlere göre daha yüksektir.

Tablo 5. Taraftarlarn eFANgelizm ve Seyircilik Tutum İliskisi (Korelasyon Analiri)

\begin{tabular}{lcccccc}
\hline & & \multicolumn{5}{c}{ eFANgelizm } \\
\hline \multicolumn{1}{c}{ Seyircilik Tutum Alt Boyutları } & & Sporsever & Takım & Fanatik & $\begin{array}{c}\text { Tüm } \\
\text { Taraftarı }\end{array}$ & Seyirciler \\
\hline \multirow{2}{*}{ Şiddete Yönelik Düşünce ve Eylem Eğilimi } & & $\mathrm{r}$ & $.353^{* *}$ & $.227^{* *}$ & $.492^{* *}$ & $.623^{* *}$ \\
& $\mathrm{p}$ & .000 & .010 & .000 & .000 & 362 \\
\hline \multirow{3}{*}{ Kurumsal Aidiyet } & $\mathrm{N}$ & 126 & 128 & 108 & $.476^{* *}$ \\
& $\mathrm{r}$ & .154 & -.018 & $.209^{*}$ & .000 & 362 \\
\hline
\end{tabular}

${ }^{*} \mathrm{p}<.05 ; *^{*} \mathrm{p}<.01$ düzeyinde anlamlıdır.

Cohen vd.'nin (2007) etki büyüklüğü sinıflandırması korelasyon katsayısını yorumlamada dikkate alınmıştır. Bu sınıflandırma şu şekildedir: $0 \leq$ Etki büyüklüğü değeri $\leq 0,20$ zayıf (poor), $0,21 \leq$ Etki büyüklüğü değeri $\leq 0,50$ küçük (modest), $0,51 \leq$ Etki büyüklüğü değeri $\leq 1,00$ orta (moderate) ve 1,01 $\leq$ Etki büyüklüğü değeri güçlü (strong) düzeyde etkisi vardır.

Tablo 5 incelendiğinde sporsever, takım taraftarı ve fanatik seyircilerin eFANgelizm puanları ile seyircilik tutum ölçeğinin şiddete yönelik düşünce ve eylem eğilimi alt boyut puanı arasında küçük (modest) düzeyde pozitif yönde anlamlı ilişki $\left(\mathrm{r}_{\text {sporseverler }}=.353, \mathrm{p}<.01 ; \mathrm{r}_{\text {takım taraftarları }}=.227, \mathrm{p}<.01 ; \mathrm{r}_{\text {fanatikler }}=.492, \mathrm{p}<.01\right)$ bulunmuştur. Tüm seyircilerin eFANgelizm puanları ile seyircilik tutum ölçeğinin şiddete yönelik düş̈nce ve eylem eğilimi alt boyut puanı arasında ise orta (moderate) düzeyde pozitif yönde anlamlı ilişki ( $\mathrm{r}_{\text {tüm }}$ seyirciler $=.623, \mathrm{p}<.01)$ bulunmuştur. Sporsever ve takım taraftarı seyircilerin eFANgelizm puanları ile seyircilik tutum ölçeğinin kurumsal aidiyet alt boyut puanları arasında anlamlı bir ilişki belirlenmezken (p>.05), fanatik seyircilerin eFANgelizm puanları ile seyircilik tutum ölçeğinin kurumsal aidiyet alt boyut puanı arasında küçük (modest) düzeyde pozitif yönde anlamlı ilişki $\left(\mathrm{r}_{\text {sporsever }}=.209, \mathrm{p}<.05\right)$ bulunmuştur. 
Tablo 6. Taraftarlarn eFANgelizm ve Seyircilik. Tutum İliskisi (Regresyon Analiri)

\begin{tabular}{|c|c|c|c|c|c|c|}
\hline \multicolumn{7}{|l|}{ Sporsever } \\
\hline $\begin{array}{l}\text { Yordanan } \\
\text { Değişken }\end{array}$ & Yordayan Değişkenler & $\bar{B}$ & $\begin{array}{c}\text { Standart } \\
\text { Hata }\end{array}$ & $\beta$ & $\mathrm{t}$ & $\mathrm{p}$ \\
\hline \multirow{4}{*}{ eFANgelizm } & (Sabit) & 1.838 & .476 & & 3.864 & .000 \\
\hline & Kurumsal Aidiyet & -.038 & .125 & -.029 & -.301 & .764 \\
\hline & Şiddete Yönelik Düşünce ve Eylem Eğilimi & .666 & .176 & .367 & 3.774 & .000 \\
\hline & $\begin{array}{l}\text { Multiple } \mathrm{R}=.354 \mathrm{R}^{2}=.125 \\
\text { Adj } \mathrm{R}^{2}=.111 \mathrm{~F}_{(2,123)}=8.784 . \mathrm{p}=0.00<.05\end{array}$ & & & & & \\
\hline \multicolumn{7}{|c|}{ Takım Taraftarı } \\
\hline $\begin{array}{l}\text { Yordanan } \\
\text { Değişken }\end{array}$ & Yordayan Değisşkenler & B & $\begin{array}{c}\text { Standart } \\
\text { Hata }\end{array}$ & $\beta$ & $\mathrm{t}$ & $\mathrm{p}$ \\
\hline \multirow{4}{*}{ eFANgelizm } & (Sabit) & 1.618 & .843 & & 1.919 & .057 \\
\hline & Kurumsal Aidiyet & .063 & .245 & .023 & .257 & .798 \\
\hline & Şiddete Yönelik Düşünce ve Eylem Eğilimi & .796 & .305 & .231 & 2.610 & .010 \\
\hline & $\begin{array}{l}\text { Multiple } \mathrm{R}=.228 \mathrm{R}^{2}=.052 \\
\text { Adj } \mathrm{R}^{2}=.037 \mathrm{~F}_{(2,125)}=3.429 . \mathrm{p}=0.04<.05\end{array}$ & & & & & \\
\hline \multicolumn{7}{|l|}{ Fanatik } \\
\hline $\begin{array}{l}\text { Yordanan } \\
\text { Değişken }\end{array}$ & Yordayan Değişkenler & $\bar{B}$ & $\begin{array}{c}\text { Standart } \\
\text { Hata }\end{array}$ & $\beta$ & $\mathrm{t}$ & $\mathrm{p}$ \\
\hline \multirow{4}{*}{ eFANgelizm } & (Sabit) & .048 & .480 & & .099 & .921 \\
\hline & Kurumsal Aidiyet & .137 & .392 & .032 & .349 & .728 \\
\hline & Şiddete Yönelik Düşünce ve Eylem Eğilimi & 1.512 & .288 & .480 & 5.251 & .000 \\
\hline & $\begin{array}{l}\text { Multiple } \mathrm{R}=.492 \mathrm{R}^{2}=.243 \\
\text { Adj } \mathrm{R}^{2}=.228 \mathrm{~F}_{(2,105)}=16.810 . \mathrm{p}=0.00<.05\end{array}$ & & & & & \\
\hline \multicolumn{7}{|c|}{ Tüm Seyirciler } \\
\hline $\begin{array}{l}\text { Yordanan } \\
\text { Değișken }\end{array}$ & Yordayan Değişkenler & $\bar{B}$ & $\begin{array}{c}\text { Standart } \\
\text { Hata }\end{array}$ & $\bar{\beta}$ & $\mathrm{t}$ & $\mathrm{p}$ \\
\hline \multirow{4}{*}{ eFANgelizm } & (Sabit) & 1.254 & .136 & & 9.218 & .000 \\
\hline & Kurumsal Aidiyet & -.135 & .100 & -.096 & -1.352 & .177 \\
\hline & Şiddete Yönelik Düşünce ve Eylem Eğilimi & .987 & .100 & .702 & 9.848 & .000 \\
\hline & $\begin{array}{l}\text { Multiple } \mathrm{R}=.626 \mathrm{R}^{2}=.391 \\
\text { Adj } \mathrm{R}^{2}=.388 \mathrm{~F}_{(2,359)}=115.375 . \mathrm{p}=0.00<.05\end{array}$ & & & & & \\
\hline
\end{tabular}

Tablo 6 incelendiğinde sporsever seyircilerin eFANgelizm düzeyi, kurumsal aidiyet ve şiddete yönelik düşünce ve eylem eğilimi ile anlamlı bir model oluşturmaktadır. Kurumsal aidiyet ve şiddete yönelik düşünce ve eylem eğilimi birlikte sporsever seyircilerin eFANgelizm düzeyi toplam varyansının $\% 12,5$ 'ini açiklamaktadır $\left(\mathrm{R}=.354 \mathrm{R}^{2}=.125, \mathrm{~F}_{(2,123)}=8,784, \mathrm{p}=0,00<.05\right)$.Şiddete yönelik düşünce ve eylem eğiliminin modele anlamlı katkı sağladığ1 görülürken kurumsal aidiyet tek başına modele anlamlı katkı sağlamamaktadır.

Takım taraftarı seyircilerin eFANgelizm düzeyi, kurumsal aidiyet ve şiddete yönelik düşünce ve eylem eğilimi ile anlamlı bir model oluşturmaktadır. Kurumsal aidiyet ve şiddete yönelik düşünce ve eylem eğilimi birlikte takım taraftarı seyircilerin eFANgelizm düzeyi toplam varyansının $\% 5$, 2'sini açıklamaktadır $(\mathrm{R}=$ $\left..228 \mathrm{R}^{2}=.052, \mathrm{~F}_{(2,125)}=3,429, \mathrm{p}=0,00<.05\right)$. Modele anlamlı katkıyı sadece şiddete yönelik düşünce ve eylem eğilimi sağlamıştır.

Fanatik seyircilerin eFANgelizm düzeyi, kurumsal aidiyet ve şiddete yönelik düşünce ve eylem eğilimi ile anlamlı bir model oluşturmaktadır. Kurumsal aidiyet ve şiddete yönelik düşünce ve eylem eğilimi birlikte fanatik seyircilerin eFANgelizm düzeyi toplam varyansının \%24,3'ünü açılamaktadır $(\mathrm{R}=.492$ $\left.\mathrm{R}^{2}=.243, \mathrm{~F}_{(2,105)}=16,810, \mathrm{p}=0,00<.05\right)$. Modele anlamlı katkıyı sadece şiddete yönelik düşünce ve eylem eğilimi sağlamıştır.

Tüm seyircilerin eFANgelizm düzeyi, kurumsal aidiyet ve şiddete yönelik düşünce ve eylem eğilimi ile anlamlı bir model oluşturmaktadır. Kurumsal aidiyet ve şiddete yönelik düşünce ve eylem eğilimi birlikte tüm seyircilerin eFANgelizm düzeyi toplam varyansının \%39,1'ini açılamaktadır $\left(\mathrm{R}=.626 \mathrm{R}^{2}=.391, \mathrm{~F}\right.$ $\left.{ }_{(2,359)}=115,375, \mathrm{p}=0,00<.05\right) \cdot$ Modele anlamlı katkıyı sadece şiddete yönelik düşünce ve eylem eğilimi sağlamıştır. Bulgulara göre sporsever, takım taraftarı ve fanatik seyircilerin şiddete yönelik düşünce ve eylem eğilimi arttıkça eFANgelizt davranışlara olan yönelme artmaktadır. 
Tablo 6 incelendiğinde tüm seyirciler ele alınarak kurulan modelin çalıştığının görülmesine karşın, fanatik seyirci açısından kurulan modelin sporsever, takım taraftarı için kurulan modellere göre eFANgelizm düzeyini açılamada daha yeterli olduğu görülmüştür.

\section{Tartışma, Sonuç ve Öneriler}

$\mathrm{Bu}$ çalışmanın amacı, futbolda farklı seyirci gruplarının (seyirci, taraftar ve fanatik) spor takımı eFANgelizm düzeylerinin incelenmesidir. Araştırmaya katılan taraftarların seyircilik durumlarına göre \% 34,8’i fanatik, \% 35,4’ü takım taraftarı ve \% 29,8'i ise sporsever olduğu görülmektedir. Bu durum, insanların takım takip düzeylerinin farklılık gösterdiği yönündeki varsayımı (Katz-Navon ve Timmor 2012) pekiştirmektedir.

Araştırma sonuçlarına göre seyirci gruplarına göre spor takımı eFANgelizminin farklılaştı̆̆ görülmektedir. Seyirci gruplarının eFANgelizm düzeyine göre hangi alt gruplar arasında farklılaştığını incelediğimizde, sporseverlerin eFANgelizm düzeyi fanatik ve takım taraftarlarına göre daha düşük olduğu görülmektedir. Spor takımı eFANgelizmi, aktif olarak başkalarının satın alma davranışını pozitif yönde etkilemek için bir taraftarı olduğu takımın tanıtımını yapılması ve takımla ilgili iyi haberlerin yayılmasına katk1 sağlayan ve bu katkıyı herhangi bir beklenti içerisine girmeden gerçekleştirmek olup (Matzler vd., 2007) takım sadakatinin de ötesinde bir kavramdır. Bununla birlikte evangelizm sözlü iletişimlerden daha fazlasını içerebilir ve çeşitli farklı davranışları kapsayabilir. Brewer (1991) grup üyeliğinin, birinin ayırt ediciliğini belirlemede önemli bir araç olduğunu belirtmiştir. Ayrıca, Katz-Navon ve Timmor (2012) farklı grupların, farklılık arzusuna dayanan ürün ve hizmetlerle farklı şekilde etkileşime girdiğini tespit etmiştir. Wann ve Branscombe (1993), spor izleyicileri arasındaki bariz farklardan ötürü, izleyicilerin hepsinin aynı olduğu varsayımıyla incelemenin doğru olmadığını belirtmektedir. Jones (1997) taraftarların tutmuş olduğu takımı daha yoğun şekilde takip eden ve her gününün bir parçasını tutmuş olduğu takıma ayırıp kendilerini ona adarlar iken, seyircilerin genellikle bir spor müsabakasını izlediklerini ve bunu unuttuklarını öne sürmektedir (Mountinho, Dionisio ve Leal, 2007, s. 670). Bu bilgi ve bulgular araştırma sonucunda ortaya çıkan farklı izleyici guruplarının farklı sadakat ve eFANgelizm davranışı sergiledikleri sonucunu desteklemektedir. Ayrıca Inoue vd. (2017) yaptıkları çalışmada sosyal kimliğin bir parçası olarak kabul edilen taraftarlık davranışının takımın müsabakalarına katılmaktan duygusal bağlar kurmaya kadar çeşitli davranışların tetikleyicisi olduğunu ifade etmişlerdir. Kwon ve Kwak (2014) da yaptıkları çalışmada duygusal, sosyal ve fonksiyonel tüketici değerlerinin ve takım kimliğinin lisanslı ürün satın alma davranışı üzerine etkili olduğunu ortaya koymuşlardır. Bu açıdan değerlendirildiğinde bu çalışmaya konu olan eFANgelizm davranışının sosyal kimlik teorisi çerçevesinde seyirci grup farklılığını ortaya koyması belirtilen araştırma sonuçlarıla da benzerlik göstermektedir.

Taraftarların seyircilik tutum (kurumsal aidiyet ve şiddete yönelik düşünce ve eylem eğilimi)düzeyinin spor takımı eFANgelizmini ne düzeyde açıklayabildiğini ortaya koymayı amaçlayan bu çalışmada; söz konusu kavramlar arasındaki doğrudan ve dolaylı ilişkiler seyirci, taraftar ve fanatik seyirciler üzerinden gerçekleştirilmiştir. Seyirci, taraftar ve fanatik seyirciler için ayrı ayrı kurulan modellerde şiddete yönelik düşünce ve eylem eğiliminin modele anlamlı katkı sağladığı görülürken kurumsal aidiyet tek başına modele anlamlı katkı sağlamadığı görülmüştür. Araştırma sonuçlarına göre, şiddete yönelik düşünce ve eylem eğilimi ve spor takımı eFANgelizmi arasında pozitif yönlü bir ilişki bulunmaktadır. Seyircilerin şiddete yönelik düşünce ve eylem eğilimi arttıkça spor takımı eFANgelizminde bir artış olduğu görülmektedir. Bu bulgu eFANgelizm kavramına farklı bir bakış açısı getirmesi bakımından oldukça önemlidir. Spor organizasyonlarında ilişki pazarlaması, seyircileri nasıl müşteri olarak çekecek, geliştirecek ve elde tutacaklarıyla ilgilenirken (Scott vd., 2017), eFANgelizmin olumlu ağızdan ağıza iletişime, kulüp hayranlığına, taraftar topluluklarının gelişimine yol açarak, sadık ve uzun vadeli müşteriler edinerek, spor organizasyonları için ortak değer yaratmaya önemli katk1 sağladığı düşünülürken (Popp, Germelmann ve Jung, 2016; Abosag vd., 2012), şiddete yönelik eğilimleri de etkilediği bu çalısmada görülmüştür. Bu açıdan değerlendirildiğinde Türk futbol taraftarının diğer taraftarlarla olan gerginliğinin ve buna bağlı olarak düşünce ve eylemlere yönelik tavırlarının eFANgelizm olgusu içinde değerlendirilmesi önemli görülmektedir.

Ayrıca fanatik seyirci açısından kurulan bu modelin sporsever, takım taraftarı için kurulan modellere göre eFANgelizm düzeyini açıklamada daha etkili olduğu görülmüştür. Sergilenen davranışın yanı sıra bağlanma düzeyleri tüm spor taraftarları için aynı değildir. Takım hayranlığıyla ile ilgili artan bağlanma ve kişisel kimliklendirme göz önüne alındığında (Branscombe ve Wann, 1991), fanatiklerin taraftarlara ve seyircilere göre takımla ilgili iletişimlerinin daha tutkulu ve duygusal olmasını beklemek mantıklıdır. Futbol 
takımlarının spor takımı eFANgelizmini destekleyen çalışmalar içerisinde bulunması sadık, takımını benimsemiş, gerektiğinde savunuculuğunu yapacak ve düzenli olarak gelir kaynağı sağlayacak taraftarları yaratmada etkili olsa da şiddete yönelik düşünce ve eylem eğilimini de arttırması kulüp yöneticileri ve spor pazarlamacıları için üzerinde durulması gereken bir durumdur. Bu durumda aklın ötesinde bir bağglliğ1 ifade eden eFANgelizmin şiddete buradan da holiganizme doğru eğrilmesi kaçınılmaz bir durum olabilir. $\mathrm{Bu}$ nedenle taraftar gruplarının davranışlarının kabul edilebilir normlarda olması için bu grupların davranışlarının belirlenmesi, denetlenmesi ve eğitilmesi fanatik davranışların önlenmesinde oldukça önem arz etmektedir. Yine de, bu anlatılanlar doğrultusunda bu konuda daha fazla araştırma yapılması önerilmektedir.

\section{Etik Beyan}

"Futbol Taraftarlarmm Seyircilik Durumlar ile Spor Takımı Evangelizm (eFANgeližm) İliskisi Üzerine Ampirik Bir Araştırma" başlıklı çalışmamızın yazım sürecinde bilimsel, etik ve alıntı kurallarına uyulmuş; toplanan veriler üzerinde herhangi bir tahrifat yapılmamış ve bu çalşsma herhangi başka bir akademik yayın ortamına değerlendirme için gönderilmemiştir. Bu araştırmanın verileri 01.01.2020 tarihinden önce toplandığı için etik kurul kararı zorunluluğu taşımamaktadır.

\section{Teşekkür}

Çalışmamızda bizlerden katkı, destek ve ilgilerini eksik etmeyen danışman hocamız Prof. Dr. Erkan Faruk Şİİ̀N’e teşekkür ederiz.

\section{Kaynakça}

Abosag, I., Roper, S. ve Hind, D. (2012). Examining the relationship between brand emotion and brand extension among supporters of professional football clubs. European Journal of Marketing, 46, 1233-1251.

Büyükakgül, Ü. C., Yüce, A. ve Katırcı, H. (2018). Futbol takımlarının amaca yönelik pazarlama uygulamalarının efangelizm davranışı üzerine etkisinin incelenmesi. Uluslararası Rekreasyon ve Spor Yönetimi Kongresi, 10-13 Mayıs, Bodrum. ss. 197-198.

Büyükakgül, Ü. C. ve Engin, S. G. (2018). Spor tüketicisinin yeni sadakat anlayışı: Efangelizm. 22. Paz̧arlama Kongresi. 28-30 Eylül Trabzon. ss. 796-804.

Dwyer, B., Greenhalgh, G. P. ve LeCrom, C. W. (2015). Exploring fan behavior: Developing a scale to measure sport eFANgelism. Journal of Sport Management, 29(6). http://dx.doi.org/10.1123/JSM.2014-0201

Hsu, L. C. (2018) Investigating the brand evangelism effect of community fans on social networking sites: Perspectives on value congruity. Online Information Review https://doi.org/10.1108/OIR-06-2017-0187.

Küçükibiş, H. F. ve Yurtsızoğlu, Z. (2019). Investigation of the evangelism of sport team's attitudes of the high school students. Journal of Education and Training Studies, 7(3S), 106-113.

Matzler, K., Pichler, E. A. ve Hemetsberger, A. (2007). Who is spreading the word? The positive influence of extraversion on consumer passion and brand evangelism. Marketing Theory and Applications, 18(1), 25-32.

Pimentel, R. W. ve Reynolds, K. E. (2004). A model for consumer devotion: affective commitment with proactive sustaining behaviors. Academy of Marketing Science Review, 5(1), 1-45.

Popp, B., Wilson, B., Horbel, C. ve Woratschek, H. (2016). Relationship building through Facebook brand pages: The multifaceted roles of identification, satisfaction, and perceived relationship investment. Journal of Strategic Marketing, 24, 278-294.

Roberts, K. (2004). Lovemarks: The future beyond brands. NY: Powerhouse Books.

Scott, O., Naylor, M. ve Bruffy, K. (2017). Social media, fan engagement and global sport. In N. Schulenkorf ve S. Frawley (Eds.). Critical issues in global sport management (pp. 141-151).Abingdon: Routledge.

Sivrikaya, M. H. (2015). Üniversite ögrencilerinin düzenli egzersiz yapmaya yönelik davranss değgsstirme istekleri ile taraftarllk seviyeleri arasindaki ilişki (Doktora Tezi). Atatürk Üniversitesi, Sağlık Bilimleri Enstitüsü, Erzurum.

Taşmektepligil, M. Y., Çankaya, S. ve Tunç, T. (2015). Futbol taraftarı fanatiklik ölçeği. Spor ve Performans Araştırmalar Dergisi, 6(1), 41-49.

Wann, D. L., Grieve, F. G., Zapalac, R. K.ve Pease, D. G. (2008). Motivational profiles of sport fans of different sports. Sport Marketing Quarterly, 17(1), 6-19.

Yoshida, M., Gordon, B., Nakazawa, M. ve Biscaia, R. (2014). Conceptualization and measurement of fan engagement: Empirical evidence from a professional sport context. Journal of Sport Management, 28, 399-417.

Yüksekbilgili, Z. (2017). Spor takımı evangelizmi (eFANgelizm) ölçeğinin Türkçeye uyarlanması: Güvenirlik ve geçerlilik çalışması.Yönetim ve Ekonomi, 24(3), 959-969.

Yüksekbilgili, Z. (2018). Sport eFANgelism demographics. International Journal of Advanced Multidisciplinary Research and Review, 6(9), 40-46. 


\section{EXTENDED ABSTRACT}

Brand evangelism, which is a way of advanced marketing advocated by consumers voluntarily in the name of brands, may gain many favors for a company. One of the most important concepts in brand evangelism is commitment. Primary purpose of sport organizations which have fans is to create sport consumers that are committed to them. Coming to the forefront with its relationship with a team brand; eFANgelism consists of the behaviors of fans whose team-related beliefs are evoked and which finally spread passionately, as well as team-centered interactions. There is not much information or data regarding the examination of the relationship between the concept of loyalty and favour in sports. In addition, we have encountered no national or international study focusing on the relationship between fan behaviors and evangelism (eFANgelism), either. Thus, in this study which was conducted under the guidance of social identity theory, it was aimed to reveal the relationship between the audience, fan and fanatic attitudes on the basis of sport team evangelism and similar psychometric and behavioral measurements of football audiences. Therefore, it is believed that the results of this study will contribute to the extension of the database concerning sport consumer behaviors.

In this research, it was aimed to reveal the correlation between sport team evangelism and the spectator, fan and fanatic attitudes of football spectators. In accordance with these goals, Descriptive Analysis and Relational Research Model were used. Target population of the study consisted of the audiences of professional football clubs in Turkey, while the sample consisted of university student football audiences of Besiktas, Fenerbahce, Galatasaray and Trabzonspor football clubs, who agreed to participate in the study voluntarily in the 2018-2019 season of the Turkish Football Super League, in the province of Konya. Due to lack of a certain number of audiences or an available fan list and time-cost limitations, the study group was limited to university students (undergraduate and postgraduate). The study group consisted of 362 university students studying in Konya and supporting Besiktas ( $\mathrm{n}=84$ ), Fenerbahce ( $n=95)$, Galatasaray $(n=151)$ and Trabzonspor $(n=32)$. Data were collected using "Football Fans' Fanaticism Scale" which aimed to determine the levels of football spectators (spectator, fan, fanatic) and "Sport Team Evangelism (eFANgelism) Scale" which aimed to determine fan behaviors evoked by spreading the team-related beliefs and team-centered interactions of football spectators passionately. In the analysis of the data, normality was tested and it was determined that the data were normally distributed using parametric tests.

In the data analysis, normalcy was tested and it was determined that the data were normally distributed using parametric tests. In addition, multiple groups were compared using one-way analysis of variance (ANOVA). The Tukey HSD test was used to determine between what groups the differences were; Pearson's correlation analysis to determine the relationship between audience attitudes and eFANgelism levels; regression analysis to determine the effect of corporate belonging attitudes of tendency to violent thoughts and actions on sport team eFANgelism levels.

According to the Football Fans' Fanaticism Scale, 34,8\% (126) of the football spectators who participated in the research were fanatics, $35,4 \%$ (128) were fans and 29,8\% were spectators (sports fans). Among football spectators, the fanatics were found to have significantly higher levels of sport team eFANgelism in all lower dimensions (defence, commercials, incitement and assimilation), compared to spectators and fans. In addition, it was determined that there was a positive correlation between the lower dimensions of sport team eFANgelism (defence, commercials, incitement and assimilation) and the lower dimensions of football spectator fanaticism (tendency to violent thoughts/actions and corporate belonging). From this point of view; it is possible to state that fanatic and fan eFANgelists contribute to the spread of team-centered interactions by introducing their teams without any expectations.

Although the involvement of football clubs in studies supporting sport team eFANgelism is effective on creating loyal fans who have adopted their team, will defend it whenever necessary and provide a regular source of income; it increases tendency to violent thoughts and actions, which should be taken into consideration by club managers and sport marketeers. In this case, it might be inevitable for eFANgelism which expresses a commitment beyond reason to turn into violence and then into hooliganism. Thus, in order for fan group behaviors to be acceptable, it is of prime importance to determine, inspect and train the behaviors of these groups to prevent fanatic behaviors. Yet still, it is recommended to conduct more studies on this matter in line with the aforementioned data. 